\title{
NOS3 Gene
}

National Cancer Institute

\section{Source}

National Cancer Institute. NOS3 Gene. NCI Thesaurus. Code C38570.

This gene plays a role in signal transduction, ang iogenesis and platelet aggregation. 